\title{
The effect of project-based blended learning (PJB2L) learning model on students learning outcomes
}

\author{
Mira Juwita Eva Distyasa*, Elizabeth Titiek Winanti, I.G.P. Asto Buditjahjanto, \& Tri Rijanto \\ Department of Technology and Vocational Education, State University of Surabaya, East Java, 60231, Indonesia \\ mirajuwita.18005@mhs.unesa.ac.id; titiekwinanti@unesa.ac.id; asti@unesa.ac.id; tririjanto@unesa.ac.id \\ *Corresponding Author: mirajuwita.18005@mhs.unesa.ac.id | Phone Number: +6285648482767
}

\section{ARTICLE INF0}

Received: 05-05-2021

Received in revised: 14-06-2021

Accepted: 12-07-2021

Available online: 30-8-2021

\section{KEYWORDS}

Learning model project;

Based blended learning

Learning outcomes;

Basic graphic design;

\section{A B S T R A C T}

The main problem in education today is the lack of effectiveness in the learning process. This can be seen from the average student learning outcomes which are always still low. Especially for vocational high school students who emphasize learning skills in order to produce work-ready graduates, but it is inversely proportional to the facts in the field. Low learning outcomes are indicated because the learning conditions are still conventional (lectures, practicum, and discussions) where teachers are stil a source of learning (teacher centered). This study aims to determine the effect of the project based blended learning model on learning outcomes of vocational high school students. This research was conducted through a literature review and relevant research results and was continued through a Focus Group Discussion (FGD). From the research it was found that there was a significant positive influence between the variable model of project based blended learning and student learning outcomes, which means that student learning outcomes can be improved through the application of a project based blended learning model.

\section{INTRODUCTION}

The development of a country cannot be separated from the role of education. Education is one form of human manifestation that is dynamic and full of development. Therefore, changes or developments in education are things that should occur in line with changes in educational culture. Changes in the sense of improvement in education at all levels need to be continuously carried out as. Anticipating future interests and demands of modern society (Amri, 2013, p.1) Entering the 21st century, the field of Information and Communication Technology (ICT) is growing rapidly, this development affects various aspects of life, including aspects of education that are required to follow the direction of that development.

In recent years there have been many problems in the world of education, effectiveness in the learning process has become a major problem. Especially for vocational high school students (Vocational High School) it has the aim of producing graduates who are skilled, competent, and able to compete in the world of work. Although vocational high school has emphasized learning skills in order to produce work-ready graduates, it is inversely proportional to the facts in the field. Based on data from the Central Statistics
Agency (BPS) in 2019, in the last year, unemployment decreased by 50 thousand people, in line with the Open Unemployment Rate (TPT) which fell to $5.01 \%$ in February 2019. Judging from the level of education, SMK graduates still dominate TPT in Indonesia compared to other education levels, namely $8.63 \%$. This result is of course inversely proportional to the goal of SMK, which is to produce graduates who are able to compete in the world of work. This will become a serious problem, if improvements are not made in the education system in order to improve the quality of student graduates. The first step that can be taken to improve the quality of student graduates is to improve the existing learning system in schools. Starting with improving the learning model used by the teacher in the learning process. Currently, many teachers in schools are still using conventional learning models where the teacher is still a source of learning (teacher centered). Students are emphasized to hear and get all information from the teacher, so that it makes students bored during learning activities and the material presented by the teacher cannot be absorbed properly. The use of this learning model limits the thinking process and skills of stu- 
dents. Students become passive and find it difficult to develop. One of the competencies that grade $\mathrm{X}$ vocational students who study Information and Communication Technology (ICT) must have is competency in basic graphic design subjects.

Graphic design basics are the basic subjects of vocational high school class $\mathrm{X}$ both in the Multimedia expertise program (MM), the Computer and Network Engineering Skills Program (TKJ) and the Software Engineering expertise program (RPL). The basis of graphic design is learning that requires high creative thinking skills. According to (M. Suyanto, 2004) the basic elements of graphic design consist of lines, shapes, textures, formats. In the basic learning of graphic design, students are taught to use several graphic design applications such as CorelDRaw and Photoshop. This subject applies theoretical learning and practical learning in its implementation. This subject applies theoretical learning and practical learning in its implementation. Students are required to be able to make sketches of images, analyze the basic scope of design, identify functions and design elements and present the results of implementing design elements, process design processing software and apply image manipulation by utilizing effect features in design. Based on these problems, the application of the model Innovative learning is needed in order to improve students' creative thinking patterns. The main problem in learning is that the absorption of students is still low because the learning model used is still using conventional learning models.

Online-based pursuit or so-called e-learning is an educational concept that utilizes information technology in the learning process. This fits with the demands of 21st century learning that all subjects must be ICT-based. According to Hartanto (2016) e-learning is an innovation that can be used in the learning process, not only in the delivery of learning material but also changes in the abilities of various competences of students. Meanwhile, according to Dahiya (2012) e-learning is information and communication technology to enable students to study anytime and anywhere.

Based on the opinion of experts, it can be concluded that through e-learning, students not only listen to the material description from the educator but also actively observe, do, demonstrate so that the material is more easily conveyed and is not limited by time because learning can be done anytime and anywhere without having to limit students. Apart from the advantages that have been mentioned, elearning also has drawbacks. According to Munir (2009, p. 176) e-learning has characteristics about distance learning and the interaction between teachers and students is less so that the relationship between teachers and students becomes less familiar. This can lead to failure in learning, because education not only emphasizes the addition of knowledge but attitude is also a measure of success in learning. Lack of interaction can hinder students' attitudes and morale. To minimize the shortcomings of e-learning, there is the term blended learning. Blended learning is an improvement of e-learning, namely virtual learning that utilizes computer media with internet or online networks without leaving direct or face-to-face learning. So that students can repeat learning in class and will be taught wherever and whenever.

According to Husamah $(2014$, p. 36) as for some of the advantages of blended learning, namely 1) students can learn the material independently by utilizing material that is available online; 2) students can have discussions with the teacher outside of class hours; 3) learning activities outside of class hours can be controlled by the teacher properly; 4) teachers can add enrichment material through internet facilities; 5) the teacher can ask students to study the material or carry out tests before learning begins; 6) the teacher can organize quizzes, provide feedback, and make effective use of test results; 7) students can share files with other students

In this study, the blended learning model combines project based learning (PjBL) for face-to-face and online / online learning or it can be called Project-based Blended Learning (PJB2L). To achieve indicators of success, and to improve student achievement in basic graphic design lessons, the project-based learning model is considered the most suitable to be applied. The project-based learning model is a learning model by focusing on life problems that are meaningful to students, the role of the teacher in presenting problems, using the mechanism of a project in front of the class and facilitating dialogue investigations (Rusman, 2010, p. 120). The benefit of this research is to provide new knowledge for teachers as an alternative learning model in delivering basic learning material for graphic design, as well as to foster students 'interest in studying the material being taught so that students' basic learning outcomes of graphic design increase.

\section{LITERATURE REVIEW}

\section{Project Based learning Model}

Project based learning $(\mathrm{PjBL})$ is a learning model that uses projects as the core learning activity. According to Boss and Krauss (2007, p. 11) "project based learning ... is a certain strategy to turn traditional classroom upside down" which means that project based learning (PJbL) is a strategy to change traditional classrooms. According to Abdullah Sani (2014, p. 172) Project based learning (PjBL) is a teaching and learning strategy that involves students to work on a real project that is useful for solving community and environmental problems. Meanwhile, according to Istarani (2011, p. 156) argues that project based learning is an innovative learning model or approach, which emphasizes contextual learning through complex activities. 
Based on the above definitions, it can be concluded that project based learning is learning that involves students in investigating problem solving and other meaningful tasks, giving students the opportunity to work independently both individually and in groups to produce real products. Project based learning has great potential to provide interesting and meaningful learning experiences for Kemendikbud students (2013, p. 216). Project based learning model is a learning model that can be used by teachers so that it automatically means that teachers use a scientific approach in their learning. The scientific approach is a learning approach in which students acquire knowledge based on scientific work methods (Kemendikbud, 2013, p. 9-11).

Through this scientific education students will not only get knowledge (knowledge) alone, but will also get the skills and attitudes needed in their future lives. In learning using project based learning, students can practice inductive reasoning. As one of the learning models in the scientific approach, the project based learning model is in accordance with Permendikbud Number 81 A of 2013 Annex IV which states that the learning process must contain 5M, namely: 1) observing; 2) ask; 3) collect information; 4) associate; 5) communicate. In learning activities using project based learning, students carry out active learning hands on (through physical activities), as well as minds on (through thinking/mental activities). This project based learning model is in accordance with the 2013 curriculum which emphasizes student-centered learning. Students are required to be active in learning through $5 \mathrm{M}$ activities (observing, asking questions, gathering information, associating, and communicating).

\section{Blended Learning Model}

Blended learning comes from English which consists of two syllables, namely Blended which means mixture and learning which means learning. Blended learning is a combination of advantages between face-to-face and virtual learning (Husamah, 2014, p. 11). This statement is reinforced by Stein \& Graham (2014) which states "Blended learning system combines face-to-face instruction with computer-mediated instruction". The combination of learning models that are historically separate between learning systems and distributed learning systems emphasizing the role of computer-based technology in blended learning. From several opinions, it can be concluded that blended learning is a combination of two learning models between conventional or face-to-face learning with modern technology-based learning models and can be in the form of online learning.
Table 1.Table 2.1Differences between Traditional Learning and Blended Learning

\begin{tabular}{ccl}
\hline \multicolumn{1}{c}{$\begin{array}{c}\text { Character } \\
\text { Learning }\end{array}$} & \multicolumn{1}{c}{ Learning } & \multicolumn{1}{c}{ Blended Learning } \\
\hline The place & Class (inflexible) & $\begin{array}{l}\text { Class / home } \\
\text { combination, library } \\
\end{array}$ \\
& & (flexible)
\end{tabular}

\begin{tabular}{|c|c|c|}
\hline $\begin{array}{l}\text { Learning } \\
\text { methodology }\end{array}$ & Offline & $\begin{array}{l}\text { Offline and online } \\
\text { learning }\end{array}$ \\
\hline Learning time & $\begin{array}{l}\text { On schedule (not } \\
\text { flexible) }\end{array}$ & $\begin{array}{l}\text { Personal preference } \\
\text { (flexible) }\end{array}$ \\
\hline $\begin{array}{l}\text { Use } \\
\text { Technology }\end{array}$ & $\begin{array}{l}\text { Don't have to use the } \\
\text { latest technology } \\
\text { (offline) }\end{array}$ & $\begin{array}{l}\text { Must use the latest } \\
\text { technology (online) }\end{array}$ \\
\hline
\end{tabular}

(Source: khandkk, 2012)

Meanwhile, according to Stein \& Graham (2014) there are several reasons or objectives why using the blended learning model, namely: (1) improving pedadogy; (2) increasing access/flexibility; and (3) increasing cost effectiveness. Meanwhile, Husamah $(2014$, p. 22) also argues that the objectives of blended learning are as follows.

1) Helping students to develop better in the learning process in accordance with learning styles and preferences in learning.

2) Provide practical-realistic opportunities for teachers and students to learn independently, be useful and continue to develop.

3) Increased scheduling flexibility for learners, by combining the best aspects of face-to-face and online learning.

\section{Learning Outcomes}

According to Watson (2002) defines learning outcomes as something that students can do now that they cannot do otherwise. Changes in people are the result of learning experiences. Meanwhile, according to Bingham (1999) states that learning outcomes are an explicit description of what is learned in students so they must know, understand and be able to do as a result of learning.

According to Dimyati (2006: 250) learning outcomes are a learning process or learning outcomes, learning outcomes are used as benchmarks to find out how far a person has mastered the material that has been taught, in line with that Donnelly and Fitzmaurice (2005) define learning outcomes as statements about what is being taught. It is expected that students can understand, know or be able to do at the end of the learning period.Based on the opinions of experts, it can be concluded that the learning outcomes are changes in behavior which are used as benchmarks to find out how much someone masters the material that has been taught. Learning outcomes according to Bloom's taxonomy are divided into 3 domains, 
namely cognitive, affective and psychomotor. (Arikunto, 2016, p. 116).

\section{a. Learning Outcomes in the Cognitive Domain}

Cognitive (Knowledge) is the result of knowing, and this occurs after a person senses a certain object. Sensing occurs through the human senses, namely the senses of sight, hearing, smell, taste and touch. Most of human knowledge is obtained through the eyes and ears. Knowledge or cognitive is a very important domain in shaping one's actions (overbehavior) (Notoatmojo, 2010).

\section{b. Affective Domain Learning Outcomes}

The affective domain is a domain related to attitudes and values, including behavioral traits such as feelings, interests, attitudes, emotions, and values Kamayani (2013). Some experts say that a person's attitude can be predicted when a person has a high level of cognitive power. The characteristics of affective learning outcomes will appear to students in various behaviors.

\section{c. Psychomotor Learning Outcomes}

Psychomotor is a domain related to skills (Skill) or the ability to act after a person has received a certain learning experience, the psychomotor aspect is a domain related to physical activity (Notoatmojo, 2010). The order of levels from the simplest to the highest is perception, readiness, mechanism, guided response, proficiency, adaptation and organization.

\section{Basic Graphic Design Subjects}

The basis of graphic design is a group of expertise subjects (C2) given to class X students in the field of information and communication technology expertise. Information technology expertise is divided into three, namely Computer and Network Engineering (TKJ), Software Engineering (RPL), and Multimedia (MM) expertise programs. The basis of graphic design is a form of visual communication that uses images as a means of conveying information.

Graphic design basic subjects are taught through theory and practice. Class X Semester 1 emphasizes more on the basics of graphic design such as layout elements in the form of lines, illustrations, typography, colors, darkness, textures, and spaces, CMYK and RGB color elements, layout principles. In Class X Semester 2, students are introduced to a vector image processing software application, students are required to create a vector image design and manipulate images using the effects feature.

\section{METHODS}

This research was conducted through a literature review of relevant references and research results and continued through a focus group discussion (FGD). The relevant references include the policies of the Government of the Republic of Indonesia, and books on vocational and vocational education. Meanwhile, a study of relevant research results is a study of research results related to: (1) a projet based learning model; (2) blended learning model; (3) the advantages of the project-based blended learning model; and (4) basic learning outcomes of graphic design. Based on the results of this study, data analysis techniques were carried out using descriptive-qualitative techniques (Sugiyono: 2006).

\section{RESULTS AND DISCUSSIONS}

As stated in the introduction, in recent years there have been many problems in the world of education, effectiveness in the learning process has become a major problem. Especially for Vocational High School students, it has the aim of producing graduates who are skilled, competent, and able to compete in the world of work. Although vocational high schools have emphasized learning skills in order to produce work-ready graduates, this is inversely proportional to the facts in the field. . This will become a serious problem, if improvements are not made in the education system in order to improve the quality of student graduates. The first step that can be taken to improve the quality of student graduates is to improve the existing learning system in schools. Starting with improving the learning model used by the teacher in the learning process. Currently, many teachers in schools are still using conventional learning models where the teacher is still a source of learning (teacher centered). Students are emphasized to hear and get all information from the teacher, so that it makes students bored during learning activities and the material presented by the teacher cannot be absorbed properly. The use of this learning model limits the thinking process and skills of students. Students become passive and find it difficult to develop. One of the competencies that grade X Vocational High School students who study Information and Communication Technology (ICT) must have is competency in basic graphic design subjects.

This can be seen from the average student learning outcomes which are always still low. There are several factors that are indicated to affect the low learning outcomes of students, namely because the current learning conditions are still conventional (lectures, practicums, and discussions) and other factors are caused by a lack of awareness in students that learning is a necessity. This needs to be overcome by choosing the right learning model. In line with this, Morisson, Ross, and Kemp (Winataputra, 2001) explain that learning models can support learning activities in understanding the theoretical framework better and apply theories to produce more effective and efficient learning activities. One of the learning models that are currently being widely adopted in learning in the field of Information and Communication Technology (ICT) is the blended learning model. Blended learning learning model 
of learning can be done online without leaving face-to-face learning, so that learning is more fun because it can be done anywhere. Teachers are required to be creative to be able to collaborate between planning skills, pedagogical teaching, and mastery of material with technology to produce creative learning that can meet student needs for today's demands. In addition to presenting interesting, efficient and meaningful yamh learning, learning should also provide opportunities and a place for students to produce certain works (Wahyudi \& Winanto Adi., 2018). All of this can be realized if the teacher does project-based learning. The process can be done in face-to-face and online classes or what is called project-based blended learning. In addition, the teacher can present online learning resources that can enrich student material.

There are a number of research results on the effect of the project-based blended learning model on student learning outcomes. Ence Surahman, et al (2019), conducted a research entitled "Students' Perception of Project-Based Learning Model in Blended Learning Mode Using Sipejar". The research concludes that the project-based learning used in the course provides satisfaction after the project is completed, project-based learning is an innovative instructional model that trains project management skills, trains a culture of cooperation, minimizes lecturer domination, is being oriented towards student optimization, trains creative thinking, trains skills cognitive on needs analysis, designs, develops, implements, and evaluates training programs, provides material cognitive, affective, and psychomotor skills and offers challenging learning.

The application of project based blended learning learning can improve student learning outcomes in line with research conducted by Adinata \& Andrias (2015) entitled "Application of blended learning learning with a project based learning model as an effort to improve learning outcomes in the Network Design Training course" found that learning outcomes aspects of knowledge in cycle I the average score of students was 74.86 with a percentage of completeness of $75.68 \%$. In the second cycle there was an increase compared to the second cycle, the average score of the students was 78.78 with a percentage of learning completeness of $83.78 \%$. The learning outcomes of the attitude aspect of the first cycle had a percentage of $69.75 \%$ and the second cycle was 75.68. While the learning outcomes of the skills aspect of the first cycle had a percentage of $72.30 \%$ and the second cycle was $84.01 \%$. The research is said to be successful if the student learning outcomes are said to be successful if the percentage of students completing learning has reached $80 \%$ in accordance with the minimum completeness criteria (KKM) determined by the school, namely 75 . Based on the results of the study it can be concluded that the application of blended learning with a project based learning model can improve learning outcomes in the aspect of knowledge in Network Design subjects.

Further research conducted by Dewi Tureni and Fatmah Dhafir (2020) entitled "The Effect of Project-Based Blended Learning Model to Improve Student Learning Outcomes of the Biology Education Study Program, FKIP Tadulak University" found that the passing rate of the experimental class was $100 \%$, while the control class was $23,33 \%$. So it shows that there is a significant difference in learning outcomes (tcount $=13.16>t_{\text {table }}=2.002$ ) between the experimental class taught using the Project-Based Blended Learning learning model and the control class using the conventional model so that it can be concluded that the learning outcomes of students using the learning model project-based learning has increased significantly.

In addition to improving learning outcomes, project based blended learning can also improve students' creative thinking skills, in line with the research conducted by Shijer lou et al (2012) entitled "Construction of a Creative Instructional Design Model Using Blended, Project-Based Learning for College. Student "found that incorporating creative instructional design in mixed, project-based learning could adequately encompass the content of the four dimensions of creativity and that this approach won the approval of most experts. This learning design model can be used as an indicator for assessing the learning effect of student creativity, as a basis for creative learning designs by teachers, and as a reference for planning creativity curricula in technical colleges. This model can effectively enhance the learning effect of students' creativity and, in turn, achieve the goal of increasing overall national competitiveness.

The application of project-based blended learning in learning can also improve students' critical thinking as evidenced by research from Permana et al (2019) entitled "Project-based learning through edmodo: improving critical thinking and histology concepts" found that there was a change in the improvement of critical thinking skills and concepts. histology of students from cycle I to cycle II. Critical thinking skills in the first cycle showed $23 \%$ complete and $77 \%$ incomplete, while the second cycle $80 \%$ complete and $20 \%$ incomplete. Critical thinking skills from cycle I to cycle II increased by 57\%. The concept of histology in the first cycle was found to be $69 \%$ complete and $31 \%$ incomplete, while the second cycle was $100 \%$ complete and $0 \%$ incomplete. The concept of histology from cycle I to cycle II increased by $31 \%$. Based on this, project-based learning through blended learning can develop students' critical thinking skills and histological concepts.

Regarding the effectiveness of the implementation of project based blended learning in learning, Wahyudi (2020) in his research entitled "The Effectiveness of Sharing Blended Project Based Learning (SBPBL) Model 
Implementation in Operating System Course" found that: (a) The model has been evaluated very practically by FGD, lecturers, and students, (b) e-book teaching materials have been evaluated very practically by FGDs, lecturers and students practice, (c) The e-learning website has been tested practically by FGD and also lecturers as was done by students, (d) Motivation of student learning increases with very high criteria. Thus it can be concluded that project based blended learning is feasible to be applied in other learning.

\section{CONCLUSIONS}

Based on a review of relevant literature and research results, and reviewed with focus group discussions (FGD), the following conclusions were obtained: (a) project based blended leraning is a learning model that is applied by combining project based learning with online learning, so that students can learn without being limited by space and time .; (b) students' basic learning outcomes of graphic design can be improved through the application of a project based blended learning model; (c) In addition to improving student learning outcomes, the application of project-based blended learning in the learning process can also improve students' creative thinking levels and critical thinking levels; (d) application of project based blended learning can also increase student motivation; (e) the success of implementing project based blended learning is very much dependent on the level of teacher creativity in delivering the material, the provision of e-book teaching materials and the learning websites used are also influencing factors; (f) there is a significant positive influence between the variable model project based blended learning and student learning outcomes, which means that student learning outcomes can be improved through the application of a project based learning model.

\section{Acknowledgement}

The authors would like to thanks the supervisors from Magister of Technology and Vocational Education, State University of Surabaya for their assistance in the completed this study.

\section{Author's Contributions}

All authors discussed the results and contributed to from the start to final manuscript.

\section{Conflict of Interest}

The authors declare that they have no competing interests.

\section{REFERENCES}

Abdullah Sani, Ridwan. (2014). Pembelajaran Saintifik untuk Implementasi Kurikulum 2013. Jakarta: PT. Bumi Aksar

Adinata, Andrias Sofian. (2015). Implementation of Blended Learning with Project Based Learning Model As Efforts to
Develope the Study Result on Subject of Stake Structure Networking in Class XISMK Negeri 1 Kota Mojokerto. Thesis. Department of Electrical Engineering, Faculty of Engineering, State University of Malang.

Amri. Sofan (2013). Pengembangan \& Model Pembelajaran Dalam Kurikulum 2013. Jakarta: PT. Prestasi Pustakakarya.

Arikunto, S. (2016). Prosedur Penelitian Suatu Pendekatan Praktik. Jakarta: Rineka Cipta.

Badan Pusat Statistik Ketenagakerjaan. (2018). Berita Resmi Statistik: Tingkat Pengangguran Terbuka (TPT) Februari 2019. No. 92/11/Th. XXI. Jakarta.

Bingham, J. (1999). Guide to Developing Learning Outcomes. The Learning and Teaching Institute Sheffield Hallam University, Sheffield. Sheffield Hallam University.

Boss, S \& Krauss, J. (2007). Reinventing Project Based Learning: Your Field Guide Real World Project in the Digital Age. Eugene, OR: International Society for Technology Education (ISTE).

Dahiya, S., Jaggi, S., Chaturvedi, K.K., Bhardwaj, A., Goyal, R.C. \& Varghese, C., (2016). An e-Learning System for Agricultural Education. Indian Research Journal of Extension Education.

Dewi , T \& Fatmah, D. (2020). Pengaruh Model Pembelajaran Project-Based Blended Learning untuk meningkatkan Hasil Belajar Mahasiswa Program Studi Pendidikan Biologi FKIP Universitas Tadulako. Jurnal Kreatif Online,8(2).

Dimyati dan Mudjiono. (2006). Belajar dan Pembelajaran. Jakarta: PT Rineke Cipta

Donnelly, R and Fitzmaurice, M. (2005). Designing Modules for Learning. In: Emerging Issues in the Practice of University Learning and Teaching, O'Neill, G et al. Dublin : AISHE.

Ence, S., , Dedi, K., Sulthoni, Agus, W., \& Zahid, Z. (2019). Perception of Project-Based Learning Model in Blended Learning Mode Using Sipejar. Proceedings of the International Conference on Education Technology (ICoET 2019).

Hartanto, Wiwin. (2016). Penggunaan E-learning Sebagai Media Pembelajaran. Jurnal Pendidikan Ekonomi : Ilmu Ekonomi dan Ilmu Sosial.

Husamah. (2014). Pembelajaran Bauran (Blended Learning). Jakarta: Prestasi Pustaka Jaya.

Istarani. (2011). 58 Model pembelajaran inovatif. Medan: Media Persada.

Kamayani, I. D., Sumantri, M., \& Sudana, D. N. (2013). Pengaruh Model Pembelajaran Project Based Lerning Berbantuan Media Tiga Dimensi Terhadap Hasil Belajar Ipa Di Sd Gugus Ix Kecamatan Buleleng. Mimbar Pgsd Undiksha, 1(1).

Kemendikbud. (2013). Model pembelajaran berbasis Proyek (Project Based Learning). Jakarta: Badan pengembangan sumber daya manusia dan penjaminan mutu pendidikan.

Khan, A.I, Noor-ul-Qayyum, Shaik. MS, Ali. AM. \& Bebi. CV. (2012). Study of Blended Learning Process in Education Context, I.J. Modern Education and Computer Science, 9, 23-29 Published Online September 2012 in MECS (http://www.mecs-press.org/) DOI: 10.5815/ijmecs.2012.09.03. 
M. Suyanto. (2004). Aplikasi Desain Grafis Untuk Periklanan. Yogyakarta: Andi.

Munir. (2009). Pembelajaran jarak jauh berbasis teknologi informasi dan komunikasi. Bandung: Penerbit Alfabeta.

Notoatmodjo, S. (2010). Metodologi Penelitian Kesehatan. Jakarta : Rineka Cipta.

Nurlaela, L., Suparji., Buditjahjanto, A. I., Sutiadiningsih, A, \& Lukitasari, F. (2019). Improving creative thinking skills through discovery learning model in vocational high schools. Jurnal Pendidikan Teknologi dan Kejuruan.

Permana, Fendy, H., \& Chamisijatin, L. (2019). Project-based learning through edmodo: improving critical thinking and histology concepts. Biosfer: Jurnal Pendidikan Biologi, 12 (1).

Rusman. (2010). Model-model Pembelajaran (Mengembangkan Profesionalisme Guru Edisi Kedua). Jakarta: Raja Grafindo Persada.

Shi-Jer, L., Chih, C., Wei-Yuan, D., \& Ru-Chu, S. (2012). Construction of a Creative Instructional Design Model Using Blended, Project-Based Learning for College Students. Journal Creative Education 2012.3 (7), 1281-1290
Stein, J \& Graham, C.R. (2014). Essentials for Blended Learning: A Standar Based Guide. USA: Routledge.

Sugiyono. (2006). Metode penelitian kuantitatif, kualitatif dan R\&D (14th ed.). Bandung: Alfabeta.

Wahyudi. (2012). The Effectiveness of Sharing Blended Project Based Learning (SBPBL) Model Implementation in Operating System Course. International Journal of Emerging Technology in Learning 15(5)

Wahyudi, W., Anugraheni, I., \& Winanto, A. (2018). Pengembangan Model Blended Learning Berbasis Proyek Untuk Menunjang Kreatifitas Mahasiswa Merancang Pembelajaran Matematika Sekolah Dasar. JIPM (Jurnal Ilmiah Pendidikan Matematika), 6(2), 68-81.

Watson, P. (2002). The role and integration of learning outcomes into the educational process. Active Learning in Higher Education. 3(3), 205-219.

Winataputra, A.S. (2001). Model-model Pembelajaran Inovatif. Jakarta: Pusat Antar Universitas untuk Peningkatan dan Pengembangan Aktivitas Instruksional, Dirjen Dikti. 